\title{
"Employees' perceptions and the relationship between human resource management and organizational performance: a conceptual view"
}

\begin{tabular}{|c|c|}
\hline AUTHORS & $\begin{array}{l}\text { Gonçalo Pombo (D https://orcid.org/0000-0002-8499-4422 } \\
\mathbb{R} \text { http://www.researcherid.com/rid/N-9244-2018 } \\
\text { Jorge Gomes } \mathbb{D} \text { https://orcid.org/0000-0003-0694-2229 } \\
\mathbb{R} \text { http://www.researcherid.com/rid/D-2231-2017 }\end{array}$ \\
\hline ARTICLE INFO & $\begin{array}{l}\text { Gonçalo Pombo and Jorge Gomes (2019). Employees' perceptions and the } \\
\text { relationship between human resource management and organizational } \\
\text { performance: a conceptual view. Knowledge and Performance Management, } \\
\text { 3(1), 46-63. doi:10.21511/kpm.03(1).2019.05 }\end{array}$ \\
\hline DOI & http://dx.doi.org/10.21511/kpm.03(1).2019.05 \\
\hline RELEASED ON & Tuesday, 24 December 2019 \\
\hline RECEIVED ON & Saturday, 26 October 2019 \\
\hline ACCEPTED ON & Thursday, 21 November 2019 \\
\hline LICENSE & $\begin{array}{l}(c) \mathbf{E Y} \\
\text { This work is licensed under a Creative Commons Attribution } 4.0 \text { International } \\
\text { License }\end{array}$ \\
\hline JOURNAL & "Knowledge and Performance Management" \\
\hline ISSN PRINT & $2543-5507$ \\
\hline ISSN ONLINE & $2616-3829$ \\
\hline PUBLISHER & LLC "Consulting Publishing Company "Business Perspectives" \\
\hline FOUNDER & Sp. z o.o. Kozmenko Science Publishing \\
\hline
\end{tabular}

NUMBER OF REFERENCES

86

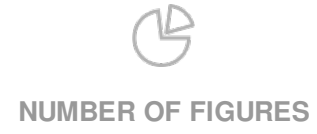

0
NUMBER OF TABLES

2

(C) The author(s) 2021. This publication is an open access article. 


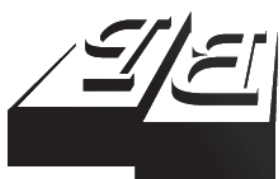

BUSINESS PERSPECTIVES

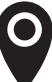

LLC "CPC "Business Perspectives" Hryhorii Skovoroda lane, 10, Sumy, 40022, Ukraine

www.businessperspectives.org

Received on: $26^{\text {th }}$ of October, 2019 Accepted on: $21^{\text {st }}$ of November, 2019

(C) Gonçalo Pombo, Jorge Gomes, 2019

Gonçalo Pombo, Msc Management, Ph.D student at ISEG - Lisbon School of Economics \& Management, Lisbon, Universidade de Lisboa, Portugal.

Jorge Gomes, Ph.D, ADVANCE/ ISEG - Lisbon School of Economics \& Management, Universidade de Lisboa, Lisbon, Portugal.

\section{(c) (i)}

This is an Open Access article, distributed under the terms of the Creative Commons Attribution 4.0 International license, which permits unrestricted re-use, distribution, and reproduction in any medium, provided the original work is properly cited.

\title{
EMPLOYEES' PERCEPTIONS AND THE RELATIONSHIP BETWEEN HUMAN RESOURCE MANAGEMENT AND ORGANIZATIONAL PERFORMANCE: A CONCEPTUAL VIEW
}

\begin{abstract}
The paper presents a review of the literature and advances a set of propositions concerning the employees' perceptions on the relationship between human resource management and organizational performance. The study is aimed at filling the gap in the literature on the employees' perception regarding human resource policies and the relationship to organizational performance. Social information processing theory is used to advance the insights on how employees' performance about human resource policies may influence the organizational performance. The review indicated that there is a positive relationship between the employees' perceptions of human resource policies and overall performance of a given organization. A positive perception of the implemented policies influences various individual outcomes such as commitment, engagement, and satisfaction, amongst others. Shared perceptions among the employees are also considered to have a considerable impact on the organizational performance. Nevertheless, there is a need for further research to explore the relationship between human resource management and organizational performance in more detail.
\end{abstract}

\section{Keywords}

JEL Classification

\section{INTRODUCTION}

There is increasing attention on the impact of human resource (HR) strategies on organizational performance (OP). This interest is based on the notion that HR needs to be considered as a strategic factor. Additionally, human resource policies (HR policies) can serve as a critical source of sustainable performance (Pombo \& Gomes, 2018), particularly when aligned with the objectives of the organization (Kehoe \& Wright, 2013). Properly configured HR strategy has the potential to contribute to direct economic gains in OP, i.e., performance refers to the results, or outputs, intended by an organization. Most past studies have focused on the positive impacts of HR policies on OP and towards the strategic behaviors. Less attention has been given to the perception of employees on OP (Kehoe \& Wright, 2013). Employees' perception is related to their attitudes (Pombo \& Gomes, 2018) such as job satisfaction and the commitment to the organization, amongst others. Recent empirical research suggests that employees' perception on resource management varies from organization to organization (Hinkin \& Tracey, 2010; Liao, Toya, Lepak, \& Hong, 2009).

According to Wang and Hwang (2012), perception is an attitude addressing the HR policies in relation to recognition, pay, quality of working life, and promotion. Employees' perceptions of fairness 
have the potential to influence the productivity, as well as performance of an organization (Li, Rees, \& Branine, 2019). When employees have the feeling that they are being treated fairly, they tend to be satisfied (Nadda, Rahimi, Dadwal, \& Bhan Singh, 2014). Although the policies generate the commitment and job satisfaction, Pombo and Gomes $(2018$, p. 66) argued that policies are also mediated by the way management applies them, and by how these are embraced by employees. Additionally, perception is viewed as a process (Ofori, Sekyere-Abankwa, \& Borquaye, 2012) where the individual relates the environment to the perceiver's potential action. Cesário (2015) recognizes that research has shown a positive impact of HR policies on OP and behavior effects, however, less attention has been dedicated to how HR policies relate to OP. In addition, past studies have ignored the impact of employees' perceptions of HR policies on OP. Similar stance had already been advanced by Boxall and Macky (2009), and Wright and Nishii (2007) who have further pinpointed that employees' perception to HR policies is scarcely used to examine the effects of HR policies on OP. Consequently, the current literature review aims at investigating how managers' and employees' shared perception of human resource management (HRM) influences the OP relationships.

To assess the influence of HR policies on OP, past research has suggested that it is essential to consider how staff perceive real HR practices (Nishii, Lepak, \& Schneider, 2008; Snape \& Redman, 2010; Maheshwari \& Vohra, 2015). Cafferkey, Heffernan, Harney, Dundon, and Townsend (2018, p. 3026) highlight the importance of research that "brings workers back into the debate by exploring employees' opinions of, and subsequent reaction to, HRM initiatives." This paper focuses on enhancing the understanding of how employees' perceptions of HR policies are associated with performance outcomes. Scholars have recommended that further studies examine the staff's perceptions of a given organization's HR system (Khilji \& Wang, 2006; Nishii, Lepak, \& Schneider, 2008). This is because the way employees perceive or experience their organizations' HR strategies has an impact on their behaviors and attitudes (Pombo \& Gomes, 2018). HR policies are perceived by staff as a commitment to the organization. This, in turn, is reciprocated to the organization by staff via positive behaviors or attitudes (Li, Rees, \& Branine, 2019). A positive perception in relation to organizational support is likely to translate to higher employees' engagement and improved OP (Pombo \& Gomes, 2018). Moreover, they are likely to extend their stay in their current organization as well as invest their effort in their positions. Employees who have positive perception of their organizational HR policies are more likely to become more engaged with their current jobs and thereby become more productive (Snape \& Redman, 2010; Conway \& Monks, 2009).

Past literature shows that strategic HRM tends to enhance the overall performance, as well as reduce staff turnover (Guchait \& Cho, 2010; Wheeler, Harries, \& Harvey, 2010). Commitment-driven HR policies tend to yield superior results in OP and are focused on the long-run mutual exchange relationships (Cooke \& Saini, 2010; Thite, Wilkinson, \& Shah, 2012). Employees' behavior is largely influenced by perceptions of HR policies (Pombo \& Gomes, 2018; Li, Rees, \& Branine, 2019). As such, there is a need to understand the how employees' perception affect the relationship between HR policies and OP outcomes. The current paper uses social information processing theory and attributions theory to explore the following research problems:

1) Does employee's attribution to HR policies change over time? Is this variation mediated by the relationship with the line manager?

2) Do employees' attributions of HR policies affect the relationships with line managers? Are employees' outcomes such as job satisfaction, career development and performance meditated by the quality of this relationship?

3) Do line managers affect positively (or negatively) the attributions of HR policies? Is this moderated by the leadership style? By the characteristics of the leader? 


\section{LITERATURE REVIEW}

\subsection{Social processing theory}

The review is guided by the social information processing theory. This model offers a valuable theoretical framework for integrating, as well as intellectualizing deliberate and automatic processes in the organizations (Wyer Jr, 2012). The model asserts that people tend to be motivated to communicate with each other to develop the unambiguous and unwavering interpretations of their meanings and events. The theory further posits that individuals use information obtained from others within their social setting to form their attitudes, perceptions, and behaviors. The social information processing theory postulates that social setting influences the employees' perception of HR policies.

Moreover, the theory has been used to explain the occurrence of mutual perceptions among staff. This is attributed to the exposure of similar information regarding the work environment and communication with one another (Lam, Huang, \& Janssen, 2010). The theory has been widely employed to explain the impact of social setting, for example, co-workers and leaders on staff's perceptions, attitudes, or job satisfaction (Bhave, Kramer, \& Glomb, 2010). In addition, social processing theory can be used to explain how people perceive, as well as interpret the HR policies (Wright \& Nishii, 2007). Within a work environment, co-workers alongside managers can be perceived as the immediate social setting for staff.
As such, HR perceptions of co-workers and managers are expected to relate to the staff's perceptions due to several reasons, as shown in Table 1.

\subsection{Attribution theory}

Attribution theory is also used to understand the employees' perceptions of HR policies. Attribution theory was proposed by Kelly in 1973 (Gardner \& Wright, 2009), but it was only after the 1980s that it started being widely used in the field of HR (Hewett, Shantz, Mundy, \& Alfes, 2017).

The theory emphasizes how individuals make casual explanations of settings around them, as well as the consequences of their beliefs. It assumes that people behave just like inexperienced scientists aiming to comprehend the reasons for outcomes (Gardner \& Wright, 2009). Applying this reasoning in the context of HRM, it can be said that employees tend to make sense of the expected attitudes and outcomes. Line managers are responsible for the communication of HR policies to employees, i.e., for the signals provided (Alvesson \& Kärreman, 2007; Den Hartog, Boon, Verburg, \& Croon, 2013). Also, line managers' attributions of HR policies may differ from, and precede, employees' attribution of the same HR policies. This means that managers' attribution of HR policies spill over and influence the employees' attributions (Hewett, Shantz, Mundy, \& Alfes, 2017, p. 30). Some studies (e.g., Greenberg, 2003; Korsgaard, Brodt, \& Whitener, 2002) suggest that managers' behaviors and HR policies are equally responsible

Table 1. Theoretical perspective of the influence of individuals' behaviors, as well as attitudes

Source: Developed by the authors.

\begin{tabular}{|c|c|c|}
\hline Theoretical perspective & Brief description & Author \\
\hline $\begin{array}{l}\text { Employees' perceptions of HR } \\
\text { policies occur through their social } \\
\text { setting }\end{array}$ & $\begin{array}{l}\text { Individuals use of information obtained from others within } \\
\text { their social setting to form their attitudes, perceptions, and } \\
\text { behaviors }\end{array}$ & Bhave, Kramer, and Glomb (2010) \\
\hline $\begin{array}{l}\text { Sharing perceptions of HR policies } \\
\text { among the staff }\end{array}$ & $\begin{array}{l}\text { Employees' interactions among co-workers and managers } \\
\text { are likely to result in mutual perceptions among staff via } \\
\text { information exchange and communication }\end{array}$ & $\begin{array}{l}\text { Jiang, Hu, Liu, and Lepak (2017), } \\
\text { Kehoe and Wright (2013), Aryee, } \\
\text { Walumbwa, Seidu, and Otaye (2012), } \\
\text { Lam, Huang, and Janssen (2010) }\end{array}$ \\
\hline $\begin{array}{l}\text { Employees' perceptions of HR } \\
\text { policies based on individual } \\
\text { differences }\end{array}$ & $\begin{array}{l}\text { Employees' perceptions of HR policies are likely to be } \\
\text { affected by individual characteristics such as needs, values, } \\
\text { personality, demographic attributes, and contextual } \\
\text { characteristics (co-workers, work teams, and leaders) }\end{array}$ & $\begin{array}{l}\text { Nishii, Lepak, and Schneider (2008), } \\
\text { Wright and Boswell (2002), Guest } \\
\text { (2011) }\end{array}$ \\
\hline
\end{tabular}


for influencing the individuals' attributions of HR policies. People are likely to arrive at accurate attributions in case the perceptions of the stimuli-effect relationship are mutual. Finally, with respect to attributions-based perspectives, HR staff needs to assure that HR policies are convenient, perceived, and interpreted by both line managers and employees. This occurs through open communication ensuring that messages about the purpose of policies and procedures are clearly received by line managers, and therefore transmitted to employees (Hewett, Shantz, Mundy, \& Alfes, 2017). Effective HR policies are likely to enhance the overall commitment of the staff (Gardner \& Wright, 2009).

\section{HRM-OP RELATIONSHIP: A SET OF PROPOSITIONS}

According to Lepak, Liao, Chung, and Harden (2006), the most usually employed sets of mediating variables are categorized as "employee skills" (employee competences, including cooperation), "employee attitudes" (motivation, commitment, satisfaction), and "employee behavior" (retention, presence). Selection and training systems should, above all, reinforce the employee ability, whereas compensation, performance appraisal, and internal career opportunities should amplify the motivation (Úbeda-García, Claver-Cortés, Marco-Lajara, Zaragoza-Sáez, \& Gascía-Lillo, 2018), but it is also acknowledged that the full effect of an HRM-OP relationship is more complex than previously thought (Lepak, Liao, Chung, \& Harden, 2006). Evidently, a consistent theory that bridges and interrelates HRMOP is required (Guest, 1997). Organizations without these HR policies will most likely fail to guarantee a high level of these individuals and group outcomes. Salaries are used as exchange for work time and effort. However, HR policies are used to go beyond such expected minimum effort and work time. The goal is to achieve the discretionary behavior, i.e., employees working with diligence and dedication taking the employee-organization relationship to a level beyond formal contracts (Besanko, Deanove, Shanley, \& Schefer, 2013). Hence, workers' behavior and individual performance are more likely to be the product of three aspects:

- employees' perceptions of HR policies;
- the effect of employees' shared perception of HR policies; and

- individual differences that have been neglected in most of the research on the HRM-OP relationship (Wright \& Boswell, 2002; Guest, 2011).

The next topics present how employees' perceptions have become a critical instrument that helps to explain the relationship.

\subsection{Employees' perceptions of human resource policies and the relationship to organizational performance}

HR policies are related to outcomes via employees and their interpretations of the HRM-OP relationship (Guest, 1997). Research on HRM-OP has been mainly focused on organizational level analysis. Wright and Boswell (2002) stressed the importance of considering the research at the individual level and extending the research spectrum into an employee perspective. In sum, proposition 1 aims to capture these ideas.

Proposition 1. The association between employees' perceptions of HR policies and the overall performance tends to be different within the same organization. In detail, the effects of HR policies on staff are organizational-specific.

\subsubsection{Organizations' goal in establishing the ideal HR policies}

According to Young-Thelin and Boluk (2012), high performing organizations tend to pursue the innovative HR policies. It is important for organizations to emphasize on intensive staff interaction, development, and training to improve their performance. In addition, the quality of the HR policies essentially influences the motivation levels in the organization, as well as its employees. Sanders, Dorenbosch, and Reuver (2008) noted that it is important for staff to perceive the HR policies as unique, relevant, and internally consistent. As such, organizations are urged to establish the ideal HR policies that are suitable for them. HR policies that encourage the employees to obtain new skills are often perceived as organiza- 
tional support. This, in turn, enhances the employees' commitment, engagement, loyalty, and attachment to their organization.

\subsubsection{Supportive $H R$ policies and the sense of (un)fairness}

Sustained competitive edge requires dedicated, as well as smart employees. HR policies that involve task interdependence inspire the employees to seek information and emotional support from their co-workers. Additionally, human practices are a common source of staff's sense of fairness (Edwards, 2009). Supportive HR policies tend to indicate the management's enthusiasm to invest in staff capabilities. This induces the employee affirmation and mutuality. Hence, HR policies such as involvement during decision-making, development opportunities, and fair rewards enhance the organizational commitment and performance. Given that staff respond to HR policies, they are perceived as the source of OP (Frenkel, Restubog, \& Bednall, 2012).

In his study, Yamamoto (2013) indicated that HR policies share common features. They are founded on the premise that a greater commitment to individual's job and OP are related. HR policies further encourage staff to take part in management. Scheible and Bastos (2013) pursued a study with the aim of understanding how staff's perception of HR policies influences the organizational entrenchment, as well as commitment. He found that perception of HR policies is a primary determining factor of organizational commitment, which, in turn, has a great potential for enhancing the OP. This is attributed to a strong acceptance by employees of organizational values and goals, and to the willingness to exert more efforts towards organization success.

\subsubsection{Psychological contract for retaining critical assets}

Vermeeren, Steijn, Tummers, Lankhaar, Poerstamper, and Van Beek (2014) stated that HR policies serve as effective means of forging a psychological contract between employees and employers. Positive perceptions in relation to the organization's HR policies are, therefore, critical variables and are likely to foster the overall commitment of the employees.
Employees' perceptions facilitate the translation of how HRM is deployed at organization level (Veloso, 2010). Shaukat, Ashraf, and Ghafoor (2015) stated that HR policies tend to influence not only the perceptions of the employees but also the attitudes and organizational climate among other HR performance measures that result in enhanced OP. It is expected that HR policies tend to influence both organizational outcomes and staff outcomes. Organizations' can influence staff's perceptions of fairness through a well-written HR strategy asserting the significance of fairness. Staff further tend to exchange the efforts and display the substantial levels of commitment.

Guest (2011) postulated that employees' perceptions are largely neglected in most of the past HRM and OP studies. Nonetheless, the author noted that progressive HR policies entail training, staffing, and incentive compensations. Such HR policies are positively perceived by employees and hence have the potential of improving the OP. Similarly, Frenkel and Lee (2010) assessed whether high performing work practices such as teamwork, training, and job security have an impact on OP among South Korean organizations. Their study showed that these types of HR policies contributed to the enhanced performance. Additionally, Giauque, Anderfuhren-Biget, and Varone (2013) examined the effect of human practices on OP in their study. They surveyed Swiss cantonal public staff. The authors found out that the HR policies were tied to job satisfaction, organizational citizenship, and commitment. Furthermore, HR policies that were perceived to serve as intrinsic motivators were highly related to OP.

\subsubsection{Successful organizations influence $H R$ policies or is it the other way around?}

Hassan (2016) indicated that there is a positive correlation between HR policies and employees' performance. In addition, the performance of employees is directly related to OP. Successful organizations tend to consider HR policies as a critical aspect that directly influences the performance of their employees. HR policies applied by line managers on a daily basis tend to influence the staff's perception. Suttapong, Srimai, and Pitchayadol (2014) indicated that organizations are continuously deploying effective HR policies as a means of driving a high performance. 


\subsubsection{HR policies and the (in)direct impact on the employees' outcomes}

Stumpf, Doh, and Tymon (2010) investigated the role played by HR policies for individual, as well as OP. A survey of 4,811 employees from 32 units of 28 organizations was conducted across India. The authors focused on employees' perception of the effectiveness of precise HR policies and their relations with OP. They established that the perceived appropriateness of HR policies tends to influence the employees' perceptions and potentially improved OP. Ansari (2011) postulated that HR policies in organizations serve as a critical factor that can enhance the employees' commitment towards their organizations. It is expected that the perceptions of employees regarding the HR policies such as support, fairness, and effectiveness influences their organizational commitment.

Ferguson and Reio Jr. (2010) examined the impact of HR policies such as profit sharing, training, and development on positive organizational output, that is, OP and job performance. The findings showed that organizations can leverage on employees' perception of HR policies to improve the OP, as well as job performance. Moreover, it is suggested that HR function can have a positive impact on the OP through the deployment of supporting organization-based policies and processes that tend to motivate the staff. Additionally, Choi and Lee (2013) examined the internal HR policies that affect the OP. The authors explored the mediating impact of staff job satisfaction and show the impact of employees' perception of the usefulness of HR policies. The results revealed that there is a significant correlation between HR policies and OP. Besides, the findings indicated that employees' perception of HR policies serves as a mediator between HR and OP. The findings imply that employees' perceptions have a critical role in the association between HR policies and OP.

In their study, Tian, Cordery, and Gamble (2016) examined the impact of HR policies on employees' job engagement, as well as job performance. Using the ability motivation opportunity (AMO) model, the authors projected that motivation-enhancing HR policies result in improved job performance. The findings revealed that HR policies significantly contribute to the formation and development of job engagement, as well as employees' performance. The findings suggested that organizations can improve the OP through the deployment of suitable HR policies.

S. Yadav and D. Yadav (2013) postulated that employee's perceptions as well as willingness to adapt to HR policies, have a considerable impact on the performance of an organization. Studying the employees' perception enables the organizations to understand their behavior, as well as their source of inspiration. Furthermore, Collins and Smith (2006) found out that there is a significant association between the success of an organization and employees' perception. Additionally, the authors postulated that employees' perception and attitude are positively associated with HR policies in each organization. Also, Garg and Punia (2015) provided that the perception of employees on HR policies is related to the overall organizational productivity and outcome. Employees who have a positive or a favorable perception about HR policies are critical towards organizational optimization. Nevertheless, the differences in employees' perception are likely to arise as they tend to observe similar situations differently. Moreover, to some extent, the employees tend to perceive HR policies differently. The authors further indicated that it is employees' perception concerning the appropriateness of HR policies that tend to define the value and utility of a given organization. A positive perception of the given practices tends to imply an effective execution and active participation of the employees. This, in turn, has the potential of enhancing cost effectiveness and innovation in the organization (Garg \& Punia, 2015).

Bui, Liu, and Footner (2016) focused on the perception of HR policies from the employees' perspective. The authors established that the perceptions of HR policies trigger job motivation and job attitudes. Nevertheless, mixed perceptions on HR policies implemented by the organization might yield different outcomes (positive or negative). Tracey (2012) aimed at presenting an exhaustive explanation of the relationship between HR and OP. The author established that to realize a positive effect on OP, the HR policies are sup- 
posed to produce consistent, shared, and clear perceptions. This demonstrates that staff's perceptions have a key role towards the realization of the desired outcomes in an organization. This depends on whether the adopted HR policies cultivate a strong climate to realize high levels of performance. Tsui, Pearce, Porter, and Tripoli (1997) as cited in Khan, Awang, and Zulkifli (2013) indicated that employees' commitment is positively associated with the interaction between HR policies and staff's perceptions. Furthermore, HR policies can build positive behaviors such as satisfaction, as well as the commitment among the staff. Nevertheless, HR policies are also likely to yield negative behaviors, for example, turnover and absenteeism.

The perceived organizational support is relevant when it comes to examining the employees' emotional commitment towards their respective organizations (Kim \& Ko, 2014). Staff tend to develop beliefs regarding how their organizations value them. Positive levels of perceived organizational support have the potential of facilitating the realization of organizational goals. This is because employees can feel indebted to realizing the organizational goals due to a positive work attitude. There is strong evidence that HR policies tend to influence the employees' perceptions concerning the organizational support. In addition, employees are likely to feel that they are greatly valued in their organizations when the HR policies enhance the employees' perceptions (Kim \& Ko, 2014). Höglund (2012) indicated that HR policies normally send intentional signals to the staff. On the other hand, staff interpret, as well as make sense to form an individual understanding.

Later, research should try to understand how employees perceive and react to policies, and to what extent the existing HR policies care for workers' best interests (Ramsay, Scholarios, \& Harley, 2000). According to Awosanya and Ademola (2009), the strongest influencing factor shaping the employees' perception comes from managerial actions and behaviors. This means that employees are likely to have an important effect on OP (M. Lengnick-Hall, C. Lengnick-Hall, Andrade, \& Drake, 2009). The following discussion is captured by the concept of employees' shared perceptions.

\subsection{Effect of employees' shared perception of human resource policies on organizational performance}

Strong HR system sends the consistent and unambiguous messages to help the employees share a common understanding of what attitudes and behaviors are expected and rewarded (Jiang, Hu, Liu, \& Lepak, 2017). Therefore, shared perception is important to enhance the desired organizational goals through the accumulated employees' attributes. Without a strong HR system, employees may construct their own understanding of HR policies, which may or may not be consistent with organizational intentions (Jiang, Hu, Liu, \& Lepak, 2017). Consequently, the second proposition posits that:

Proposition 2. Shared perceptions act as a mediating factor between attitude-behavior relationship by strengthening the obligation and reciprocity in the exchange relationship

\subsubsection{HR policies that enhance the sharing among employees}

More important than just having a set of HR policies in the organization is how they are actually perceived be employees resulting in an attitude-behavior relationship that results in OP (Jiang, Hu, Liu, \& Lepak, 2017). According to Bergh, Connelly, Ketchen, and Shannon (2014), employees' shared perception of HR policies is said to have a significant impact on OP. For instance, the authors established in their study that high commitment towards the HR policies through added value of the dedicated employees contributes to organizational effectiveness and, in turn, good performance. Employees' perception of HR policies tends to focus more on the needs of the consumers, which is a common emphasis on OP. According to Bysted and Jespersen (2014), the shift of employees' perception on the HR policies focusing more on consumers' needs has given way to rational management, where satisfaction and needs of the customers are central. This is said to result in more aggressive employees thereby improving the performance. Furthermore, Elorza, Harris, Aritzeta, and Balluerka (2016) indicated that the changes in the perception of HR policies are said to diminish 
the organizational levels and frontiers of the hierarchy, which has implications on the employees, mainly the scaling down of the promotion opportunities, employment stability, change in career, as well as performance evaluation criteria. Thus, employees' perception, loyalty, and commitment towards an organization may lessen.

In addition, HR policies that enhance the sharing of knowledge or collaborative culture within an organization are usually a win situation for both the employees and the organization. At employees' level, it usually acts as the learning tool, where employees can improve their skills. On the other hand, at organizational level, the policies influence the employees' learning through sharing, as well as creating new skills, which result in the improvement of organizational innovative capacity (Devloo, Anseel, De Beuckelaer, \& Salanova, 2015). In essence, individuals' learning might have some positive impacts on the employees' intention to remain in the workplace thereby improving the organizational knowledge capacity by maintaining the human capital pool. Individual employees' who perceive that the HR policies make them feel honored and valued in their workplace will tend to reciprocate this through innovative behaviors and hard work, which would assist in accomplishing the organizational objectives. Furthermore, those employees that perceive HR policies are supportive of innovativeness would tend to reciprocate this through their innovativeness, which results in improved OP (Devloo, Anseel, De Beuckelaer, \& Salanova, 2015).

\subsubsection{Seeking to build a better organization}

Based on shared employee perception that it is them who structure the innovative ability of the organization through their resourcefulness, creativity, and intelligence, such HR policies could develop, identify, evaluate, as well as reward organizational development and growth (Elorza, Harris, Aritzeta, \& Balluerka, 2016). In addition, according to the norm of reciprocity, personnel are usually anticipated to trade their dedication and effort in implementing and generating some novel ideas for concrete incentives such as fringe benefits and pay, admittance to development programs and training, as well as social-emotional benefits like care, information sharing, and support. Such policies that show commit- ment towards employees would make them reciprocate with greater levels of flexible behaviors. As a result, shared employees' perception of such HR policies would affect OP through improved innovativeness in employees and their high commitment towards their productivity (Bysted \& Jespersen, 2014).

Employees' shared perception of the compensation system will probably increase the employees' motivation for engaging in specific duties within an organization. However, when such incentives are inherently intrinsic, employees might perceive such recompenses as a burden in doing work that they were performing out of curiosity or interest, which could lessen their attentiveness in engaging in innovative work behavior. This would, in turn, result in reduced OP. On the other hand, when employees perceive that they are intrinsically motivated, they end up perceiving their work as an extra-role behavior, which will be rewarded. As a result, they end up feeling valued and recognized, which makes them to engage in innovative work and perceive the work as extra-role that is going to be rewarded for extra effort (Cabello-Medina, López-Cabrales, \& Valle-Cabrera, 2011). Bergh, Connelly, Ketchen, and Shannon (2014) argued that employees require clear signals before to engaging in innovative work since they consider such work to be risky. Therefore, the HR policies, which provide financial rewards to employees, are expected to encourage them to be innovative while conducting their work, which results in increased organizational productivity.

Beugelsdijk (2008) argued that compensation positively influences improved OP since personnel who feel that their hard work is being compensated feel indulged in reciprocating with the unrestricted additional role exertions such as the innovative work. Thus, employees' shared perception of compensation provided by organizations might result in a sense of responsibility in giving the business exceptional input and knowledge or innovative suggestions for performance improvement. Cabello-Medina, López-Cabrales, and Valle-Cabrera (2011) indicated that compensation is said to have a significant effect on employees' innovative behavior since it could be an instrument of enhancing such behavior and could also discourage unproductivity in an organization by only rewarding those employees with innovative behaviors. 
Employees perceive training and development as one of the organizational commitments to HR, which make them feel the urge to reciprocate via positive behaviors and attitudes, which are not contractually enforceable or rewarded (Bysted \& Jespersen, 2014). In fact, the provision of training and development would signal that an organization contemplates employees as valuable aspects of its production and that it is in keen or eager to invest in them. As such, employees tend to respond to the training and development opportunity with some positive attitude towards an organization, which offers development (Elorza, Harris, Aritzeta, \& Balluerka, 2016). As a result, such shared positive attitudes would lead to behaviors that are treasured for both the organizations and employees'. When personnel recognize training and development as a valuable and helpful opportunity, they feel well prepared for evolving their skills and talents and work hard towards improved OP (Cabello-Medina, López-Cabrales, \& Valle-Cabrera, 2011).

\subsubsection{Share what you know: win-win solution}

Employees' perception of information sharing is beneficial to an organization. Based on the fact, that employees perceive sharing information pertinent since it might induce improvements by the others, might result in advantageous standards, signal low competitive conditions or result in an expectation of reputational and reciprocity impacts. In this case, employees shared perceptions that relevant information is shared with employees is anticipated to lead to higher level of innovative work engagement (Bergh, Connelly, Ketchen, \& Shannon, 2014). Nonetheless, sharing the information helps the employees to understand the objectives and goals of an organization, which assist them to associate with the set goals and help the organization to accomplish those objectives. A study by Elorza, Harris, Aritzeta and Balluerka (2016) indicated that organizations not sharing their objectives and not boosting the sharing of information could achieve negative results since employees perceive such behavior as procedurally unfair. Indeed, employees feel trusted, supported, and treated fairly whenever an organization encourages the sharing of information and they might even feel the need of reciprocating through innovativeness and hard work, which, in turn, result in increased OP (Bysted \& Jespersen, 2014).

\subsubsection{Working environment and the recognition of support}

Beugelsdijk (2008) argued that employees' perception of supportive supervision is also viewed to affect OP either negatively or positively. Supportive supervision is one of the high-commitment HR policies. Therefore, it is employees' shared perceptions that they should receive regular performance feedback from the supervisors since through regular feedback, employees feel encouraged in working hard to accomplish the organizational objectives. Bysted and Jespersen (2014) indicated that employees perceive supportive supervision as the key aspect that enhances their further development, application of ideas, and protection. Hence, employees experiencing supportive supervision have the feeling of being obliged to reciprocate by assisting their supervisors to accomplish the organization's goals. The reciprocation towards supportive supervision increases their in-role performance and could result in performance beyond their formal job description, as well as increased innovative and improved OP. Bergh, Connelly, Ketchen, and Shannon (2014) postulated that supportive supervision results in more innovativeness amongst employees if individual employees also recognize innovative climate, where creativities could be taken without any fear of ridicule. In such a scenario, employees would not just see their supervisors as supportive but would also view the wider organization as supportive since it encourages employees being innovative by rewarding their efforts accordingly. Therefore, the more employees distinguish the climate as helpful, the stronger the impact of the employees' shared perceptions of the HR policies would be on OP.

The impact that the perceived HR policies have on employees' behaviors highly depend on employees' shared perceptions of their working environment. Consequently, the relationship between HR policies and $\mathrm{OP}$ is strengthened whenever employees recognize supportive climate, which is valuable to their innovative and productive behavior (Cabello-Medina, López-Cabrales, \& Valle-Cabrera, 2011). In addition, the perceived HR policies would strengthen OP more when employees concerned perceive that their work is valued, and their innovativeness is appreciated. Such policies could create an atmosphere of risk-taking and creativity amongst employees and 
would, in turn, result in more innovative behavior and improved OP (Cabello-Medina, López-Cabrales, \& Valle-Cabrera, 2011).

According to Ostroff and Bowen (2016), HR policies are assumed to send signals, as well as communications, that staff tend to draw attributions. They then tend to cultivate an understanding regarding what is valued, rewarded, and expected. Superior HR systems entail the mechanisms that normally make several practices salient, coherent, as well as understandable. This has the potential of building the consensus among the staff concerning the practices. Additionally, a climate of shared perceptions tends to arise among the employees. Nevertheless, there is a notion that the relationships between HR and OP is not likely to manifest without collective understanding and perception of the existing practices among the employees. Besides, in the absence of strong HR policies, it is unlikely to experience the shared perceptions. Consequently, it is challenging to realize enhanced OP (Ostroff \& Bowen, 2016).

Kehoe and Wright (2013) asserted that shared perceptions tend to reflect in the context of HR policies. A strong HR system facilitates the shared perspectives regarding the practices among the employees. Additionally, shared perceptions on HR policies normally promote mutual understanding of work processes thereby enabling the staff to act as a team to realize the set organizational objectives. The lack of shared understanding tends to hamper the coordination, which makes it challenge to capitalize. Takeuchi, Chen, and Lepak (2009) stated that organizational climate can be termed as the shared perceptions among employees about practices, process, as well as types of behavior that tend to be supported and rewarded. The organization climate is basically used to capture the staff's perceptions regarding the organizational procedures or policies. This facilitates the reflection of employee perceptions of what is important and what is to be rewarded by the organization.

Given the significance of shared perceptions, it is important to devote the effort to understand how individual characteristics may influence the employees' perceptions and interpretations of $\mathrm{HR}$ policies. The next subsection highlights the individual differences and its influence on perceptions.

\subsection{Individual characteristics and the influence on performance}

The way objects are perceived by employees depend on the attributes of the object itself, the context within which it is perceived, and the characteristics of the perceiver (Brunswik, 1956). Hence, employees' perceptions about HR policies are likely to be affected by individual characteristics. Consequently, the proposition reads as follows:

Proposition 3. Individual characteristics need to account for employees' perceptions, attitudes, and behaviors to fully understand the HRM-OP relationship.

\subsubsection{Know your past to understand your future}

Nishii and Wright (2007) suggested that individual's values, personalities, and past experiences can influence how employees seek and filter the information to develop their HR perceptions. Values refer to stable life goals that people have, reflecting what is most important to them. Then, values that are important to people tend to affect the types of decisions they make, how they perceive their environment, and their actual behaviors. Shaped in early life values will affect his or her employment. Moreover, whether individuals will be satisfied at a given job may depend on whether the job provides a way to satisfy their dominant values. Therefore, understanding the employees at work requires understanding the value orientations of employees. Personality is another characteristic that can influence the HR perceptions and understanding someone's personality gives us clues about how that person is likely to act and feel in a variety of situations. Judge and Higgins (1999) affirm that part of our career success and job satisfaction later in life can be explained by our childhood personality.

\subsubsection{What is happening inside?}

Kooij, Jansen, Dikkers, and Lange (2010) highlighted that individual characteristics can affect the association between employees' perceptions of HR policies and work-related attitudes at the individual level. Employees' capabilities and needs required at work should be known by the supervisor 
(Subyantoro, 2009). So, it is important for management to create the conditions that will encourage employees to perform their responsibilities with a sense of satisfaction (Nawawi, 2001).

Individual characteristics are likely related to performance. Biographical characteristic such as age is negatively related to performance, e.g., performance declines with increasing age. Therefore, individual characteristics can shape the individual behaviors that influence motivation, initiative, and performance.

Mathis and Jackson (2006) affirm that there are four individual characteristics that affect how people can be accomplished, which include interest, identity, personality, and social background.
Furthermore, employees' proactive personality is related to personal goals and career success (Crant, 1995). Proactive staff may actively gather information of HR policies from managers and thus are more likely to perceive HR policies as what are reported by their managers.

This suggests that employees' competency needs to be stimulated through HR policies to improve some outcomes. Furthermore, to increase the employees' outcomes, it is necessary to create a flexible work structure and clear HR policies those employees feel related.

The following table summarizes the propositions and the supporting literature highlighted in this section.

Table 2. Workers' behavior and individual performance

Source: Developed by authors.

\begin{tabular}{|c|c|}
\hline Supporting literature & Summary \\
\hline \multicolumn{2}{|c|}{$\begin{array}{l}\text { 1) The association between employees' perceptions of HR policies and overall performance tends to be different } \\
\text { within the same organization. More specifically, the effects of HR policies on staff are organizational-specific }\end{array}$} \\
\hline \multicolumn{2}{|c|}{ Organizations' goal in establishing the ideal HR policies } \\
\hline Sanders, Dorenbosch, and Reuver (2008) & Employees should perceive HR policies as unique, relevant, and internally consistent \\
\hline Young-Thelin and Boluk (2012) & Competitive organizations will likely establish innovative HR policies \\
\hline \multicolumn{2}{|c|}{ Supportive HR policies and the sense of (un)fairness } \\
\hline $\begin{array}{l}\text { Edwards (2009); Frenkel, Restubog, and Bednall } \\
\text { (2012) }\end{array}$ & HR policies should be perceived as fair and equitable by employees \\
\hline \multicolumn{2}{|c|}{ Psychological contact for retaining the critical assets } \\
\hline $\begin{array}{l}\text { Vermeeren, Steijn, Tummers, Lankhaar, } \\
\text { Poerstamper, and Van Beek (2014) }\end{array}$ & HR policies help bringing together both parts, i.e., employees and employer \\
\hline Bal, Bozkurt, and Ertemsir (2014) & $\begin{array}{l}\text { Human resources are the key source of competitive edge in the organizations. HR } \\
\text { policies should emphasize that employees are critical assets to the organization }\end{array}$ \\
\hline \multicolumn{2}{|c|}{ Successful organizations influence HR policies or is it the other way around? } \\
\hline Hassan (2016) & HR policies are positively correlated to employees' performance \\
\hline Suttapong, Srimai, and Pitchayadol (2014) & $\begin{array}{l}\text { Organizations considers HR policies as a critical aspect that directly influences the } \\
\text { performance }\end{array}$ \\
\hline \multicolumn{2}{|c|}{ HR policies and the (in)direct impact on employees' outcomes } \\
\hline $\begin{array}{l}\text { Stumpf, Doh, and Tymon (2010); S. Yadav and D. } \\
\text { Yadav (2013); Collins and Smith (2006) }\end{array}$ & HR policies influence the employees' perceptions and stimulate OP \\
\hline Ansari (2011) & Related HR policies with employees' commitment \\
\hline $\begin{array}{l}\text { Ferguson and Reio Jr. (2010); Bui, Liu, and } \\
\text { Footner (2016) }\end{array}$ & $\begin{array}{l}\text { Suggested that HR function can have a positive impact on the OP through the } \\
\text { deployment of supporting organization-based policies and processes that tend to } \\
\text { motivate the staff }\end{array}$ \\
\hline Choi and Lee (2013) & $\begin{array}{l}\text { HR policies impact OP through an indirect effect that is mediated by employee's job } \\
\text { satisfaction }\end{array}$ \\
\hline Tian, Cordery, and Gamble (2016) & Related HR policies with job engagement and performance \\
\hline Garg and Punia (2015) & $\begin{array}{l}\text { Related HR policies with employee's productivity, effective execution, and active } \\
\text { participation }\end{array}$ \\
\hline
\end{tabular}


Table 2 (cont.). Workers' behavior and individual performance

\begin{tabular}{|c|c|}
\hline Supporting literature & Summary \\
\hline \multicolumn{2}{|c|}{$\begin{array}{l}\text { 2) Shared perceptions act as a mediating factor between attitude-behavior relationship by strengthening the } \\
\text { obligation and reciprocity in the exchange relationship }\end{array}$} \\
\hline \multicolumn{2}{|c|}{ HR policies that enhance the sharing among employees } \\
\hline Jiang, Hu, Liu, and Lepak (2017) & $\begin{array}{l}\text { Strong HR system sends consistent and unambiguous messages to help employees } \\
\text { share a common understanding of what attitudes and behaviors are expected and } \\
\text { rewarded }\end{array}$ \\
\hline Jiang, Hu, Liu, and Lepak (2017) & How HR policies are perceived be employees result in an attitude-behavior association \\
\hline Bergh, Connelly, Ketchen, and Shannon (2014) & Shared perception of HR policies contributes to organizational effectiveness \\
\hline Elorza, Harris, Aritzeta, and Balluerka (2016) & $\begin{array}{l}\text { Sharing perceptions diminish organizational levels and frontiers of the hierarchy with } \\
\text { benefits in the employees' perception, loyalty, and commitment }\end{array}$ \\
\hline \multicolumn{2}{|r|}{ Seeking to build a better organization } \\
\hline Elorza, Harris, Aritzeta, and Balluerka (2016) & Shared employee perception will cause organizational development and growth \\
\hline Bysted and Jespersen (2014) & $\begin{array}{l}\text { Shared employees' perception of HR policies that show commitment will likely } \\
\text { affect performance through improved innovativeness in employees and their high } \\
\text { commitment towards their productivity }\end{array}$ \\
\hline $\begin{array}{l}\text { Cabello-Medina, López-Cabrales and Valle- } \\
\text { Cabrera (2011); Bysted and Jespersen (2014); } \\
\text { Elorza, Harris, Aritzeta, and Balluerka (2016) }\end{array}$ & $\begin{array}{l}\text { Employees perceive training and development as a signal that organization } \\
\text { contemplates them as valuable resource. As such employees respond with positive } \\
\text { attitudes }\end{array}$ \\
\hline \multicolumn{2}{|r|}{ Share what you know: win-win solution } \\
\hline Bergh, Connelly, Ketchen, and Shannon (2014) & $\begin{array}{l}\text { Employees sharing relevant information between employees is anticipated to lead to } \\
\text { higher level of innovative work engagement }\end{array}$ \\
\hline $\begin{array}{l}\text { Bysted and Jespersen (2014); Elorza, Harris, } \\
\text { Aritzeta, and Balluerka (2016) }\end{array}$ & $\begin{array}{l}\text { Organizations not sharing their objectives and not boosting the sharing of information } \\
\text { could achieve negative results since employees perceive such behavior as } \\
\text { procedurally unfair }\end{array}$ \\
\hline \multicolumn{2}{|c|}{ Working environment and the recognition of support } \\
\hline Beugelsdijk (2008) & $\begin{array}{l}\text { Employees' perception of supportive supervision is also viewed either negatively or } \\
\text { positively }\end{array}$ \\
\hline $\begin{array}{l}\text { Bysted and Jespersen (2014); Bergh, Connelly, } \\
\text { Ketchen, and Shannon (2014) }\end{array}$ & $\begin{array}{l}\text { Perceived support from supervision is a key aspect that enhances employee's further } \\
\text { development, application of ideas, and protection }\end{array}$ \\
\hline \multicolumn{2}{|c|}{$\begin{array}{c}\text { 3) Individual characteristics need to account for employees' perceptions, attitudes, and behaviors to fully understand } \\
\text { the HRM-OP relationship }\end{array}$} \\
\hline \multicolumn{2}{|r|}{ Know your past to understand your future } \\
\hline Nishii and Wright (2007) & $\begin{array}{l}\text { Individual's values, personalities, and past experiences can influence how employees } \\
\text { seek and filter information to develop their HR perceptions }\end{array}$ \\
\hline Judge and Higgins (1999) & $\begin{array}{l}\text { Affirmed that part of our career success and job satisfaction later in life can be } \\
\text { explained by our childhood personality }\end{array}$ \\
\hline \multicolumn{2}{|r|}{ What is happening inside? } \\
\hline Kooij, Jansen, Dikkers, and Lange (2010) & $\begin{array}{l}\text { Highlights that individual characteristics can affect the association between } \\
\text { employees' perceptions of HR policies and work-related attitudes at the individual } \\
\text { level }\end{array}$ \\
\hline Nawawi (2001) & $\begin{array}{l}\text { Line managers should create conditions that will encourage employees to perform } \\
\text { their responsibilities with a sense satisfaction }\end{array}$ \\
\hline
\end{tabular}

\section{DISCUSSION}

The focus of the review was to present the propositions offering the potential directions for future research. The review of the past studies indicates that there is a relationship between how HR policies are perceived by employees and OP (Kehoe \& Wright, 2013; Cesário, 2015; Pombo \& Gomes, 2018). Additionally, perceptions of HR policies were found to have an impact on the outcomes of employees and organizations (Li, Rees, \& Branine, 2019). Substantial evidence to some extent supports the relationship between employees' perception and high-perfor- mance levels of organizations. Nevertheless, many of the studies reviewed have used managerial reports. Therefore, there is a need to comprehensively examine the role of employees' perceptions of HR policies and the relationship to OP.

The literature review has demonstrated that indeed there is a relationship between HR policies and the performance of organizations. This is attributed to the fact that HR policies tend to serve as a means of triggering OP, i.e., according to $\mathrm{Li}$, Rees, and Branine (2019, p. 1424), high performance and innovative HRM practices predicted 
the enhanced financial and market performance. Nevertheless, there is little research on employees' perception of HR policies and the relationship to OP (Boxall \& Macky, 2009; Wright \& Nishii, 2007). Empirical research has confirmed that employees' perceptions of HR policies are related to job satisfaction, as well as their commitment. Nevertheless, the current paper highlighted that employees' perception regarding HR policies may sometimes vary from one organization to another (Hinkin \& Tracey, 2010; Liao, Toya, Lepak, \& Hong 2009). Additionally, it was revealed that employees' perception of fair HR policies is likely to boost the productivity, as well as the performance of an organization. Furthermore, it was suggested that there is need to examine the impact of HR policies on OP through the lens of employees' perception in detail. A few scholars have recommended that additional studies need to be conducted to ascertain the relation between staff's perception on HR policies and how this relates to OP (Khilji \& Wang, 2006; Nishii, Lepak, \& Schneider, 2008).

Employees' attitudes, as well as interpretations of HR policies, form a key means of establishing the relationship between HRM and OP (Li, Rees, \& Branine, 2019). Thus, it is necessary to conduct an exhaustive study on the mediating role played by employee's perceptions when it comes to the association between HR and OP. Additionally, HR policies are largely meant to boost staff motivation, job satisfaction, and competence, which, in return, are likely to improve the OP (Jiang, Lepak, Han, Hong, Kim, \& Winkler, 2012; Messersmith, Patel, Lepak, \& Gould-Williams, 2011).

There is a supposition that effective HR policies tend to enhance the employees' overall organizational commitment and motivation. Additionally, the presence of HR policies that recognizes and rewards staff's effort is likely to yield the improved performance of an organization. As such, organizations need to formulate HR policies that stimulate the employees' sense of support by the organization. This has the potential of enhancing $\mathrm{OP}$ in the long run. The research suggests that HR policies that are positively perceived by employees are likely to have a significant impact on OP.
Therefore, successful organizations normally consider the employees' perceptions of implemented HR policies to be significant.

In some cases, employees tend to share the perceptions of HR policies. Shared perceptions are perceived to have a significant impact on the overall OP. This is a clear indication that mutual perceptions play an important role towards the attainment of the organizations' desired outcomes. This further facilitates the cultivation of strong organizational environment that contributes to the achievement of high-level performance (Tracey, 2012). Shared perceptions can enhance the employees' commitment when it comes to the accomplishment of organizations' goals, e.g., shared positive perception of fairness is likely to foster the staff's attitude to further improve their commitment to the organization (Pombo \& Gomes, 2018). In general, there are positive correlations between the degree to which organizations execute the HR policies and OP, i.e., according to Pombo and Gomes (2018, p. 66), by the way the management applies them, and how these are embraced by employees.

Hereafter, individual characteristic can influence the HR perceptions and should be considered. The latter is related to performance. Therefore, understanding someone's values and personalities is likely to help gathering knowledge to develop the HR policies more accurately. Hence, attitudes and behaviors (Pombo \& Gomes, 2018) are likely to be affected by individual characteristics and perceptions about HR policies. Some characteristics can help predict the behaviors that influence motivation, initiative, and the overall performance. The research paper established that the selection of HR policies has proved to be strategic towards the performance of organizations. As such, HR managers are supposed to concentrate on developing the favorable policies as they are related to OP. In sum, employees' perceptions on the process of information are influenced by individual's values, personalities, and past experiences. Hence, employees' perceptions about HR policies are likely to be affected by individual characteristics. 


\section{CONCLUSION}

The goal of this paper was to take a step toward identifying and addressing the influence of employees' perceptions on HRM. Nonetheless, the paper revealed that there is a gap concerning the employees' perception of HR policies and the relationship to OP. The existing studies have not exhaustively considered the role of employees' perceptions on HR policies in improving the OP (Khilji \& Wang, 2006; Nishii, Lepak, \& Schneider, 2008). New perspectives for framing the research question also may prove helpful for bridging the gap between more comprehensively examined role of employees' perceptions of HR policies and the relationship with OP. Pombo and Gomes $(2018$, p. 65) suggested that to understand this unresolved mystery, researchers, one should explore the relationship with outcomes. The available studies suggest that there is an association between perceptions of HR policies and the overall performance of a given organization. Social information processing theory and attribution theory were used to explain the anticipated associations. In addition, the social information processing theory posits that it is sensible to project the influence of social setting on employees' perceptions concerning the HR policies in an organization. Various studies reviewed were mainly on the relationship between the employees' perceptions of HR policies and OP. Additionally, the review of the existing literature in relation to the effect of shared perceptions was also conducted. Finally, the characteristics of the individual were also considered in the research. Nevertheless, the existing literature was considered insufficient.

Generally, this article proposed that HR policies when positively perceived, enhance the employees' job satisfaction and commitment. Additionally, it was highlighted in the analysis that shared perceptions of HR policies among the employees are positively related to OP. Nevertheless, it is possible for different employees, with different characteristics, to have varying perceptions concerning the existing policies. Therefore, it is important for future researchers to direct their efforts towards establishing the association between HR policies and OP by examining the role played by employees' perceptions. This has the potential of offering new insights on how employees perceive the implemented policies and how their perceptions are likely to boost the performance of the organization either positively or negatively. As such, it is important for future researchers to consider and specify the outcomes, as well as clarify how HR policies are being perceived. The need for detailed study is based on the fact that there is missing in-depth understanding of how employees perceive HR policies and how this is likely to shape their attitudes and commitment, which, in turn, enhances OP (Kehoe \& Wright, 2013). Such insights are needed to present new views of the connection between HR policies and OP.

\section{ACKNOWLEDGEMENT}

We are gratefully acknowledge financial support from FCT - Fundação para a Ciencia e Tecnologia (Portugal), national funding through research grant UID/SOC/04521/2019.

\section{REFERENCES}

1. Alvesson, M., \& Kärreman, D. (2007). Unraveling HRM: Identity, ceremony, and control in a management consulting firm. Organization Science, 18(4), 711723. Retrieved from https://www. jstor.org/stable/25146131

2. Ansari, N. G. (2011). Employee perception of HRM practices: Impact on commitment to the organization. South Asian

Journal of Management, 18(3), 122-149. Retrieved from https:// www.semanticscholar.org/paper/ Employee-Perception-of-HRMPractices\%3A-Impact-on-to-Ansa ri/9c74cfc2091a86b5f5f68f6cb6ee9 $7340 \mathrm{e} 757 \mathrm{~d} 41$

3. Aryee, S., Walumbwa, F. O., Seidu, E. M., \& Otaye, L. E. (2012).
Impact of high-performance work systems on individual- and branch-level performance: Test of a multilevel model of intermediate linkages. Journal of Applied Psychology, 97(2), 287-300. https:// doi.org/10.1037/a0025739

4. Awosanya, O., \& Ademola, O. (2009). Attitude of employees to work performance in an 
organization as a result of performance appraisal (Thesis). Blekinge Institute of Technology, School of Management. Retrieved from http://bth.diva-portal.org/ smash/get/diva2:831009/FULLTEXT01.pdf

5. Bal, Y., Bozkurt, S., \& Ertemsir, E. (2014). Determining the influence of HRM practices on increasing organizational commitment: An empirical research from Turkey. Human Capital without Borders: Knowledge and Learning for Quality of Life; In Proceedings of the Management Knowledge and Learning International Conference (pp. 1025-1033). Bangkok, Thailand: ToKnowPress. Retrieved from https://ideas.repec.org/h/ tkp/mklp14/1025-1033.html

6. Bergh, D. D., Connelly, B. L., Ketchen, D. J., \& Shannon, L. M. (2014). Signalling theory and equilibrium in strategic management research: An assessment and a research agenda. Journal of Management Studies, 51(8), 1334-1360. Retrieved from https://ideas.repec.org/a/bla/jomstd/v51y2014i8p1334-1360.html

7. Besanko, D., Deanove, D., Shanley, M., \& Schefer, S. (2013). Economics of strategy (6th ed.). New York: John Willey \& Sons, Inc. Retrieved from https://www. slideshare.net/PMDR/economicsof-strategy-6th-edition

8. Beugelsdijk, S. (2008). Strategic human resource practices and product innovation. Organization Studies, 29(6), 821-847. https://doi. org/10.1177/0170840608090530

9. Bhave, D. P., Kramer, A., \& Glomb, T. M. (2010). Work-family conflict in work groups: Social information processing, support, and demographic dissimilarity. Journal of Applied Psychology, 95(1), 145-158. https://doi. org/10.1037/a0017885

10. Boxall, P., \& Macky, K. (2009). Research and theory on highperformance work systems: Progressing the high-involvement stream. Human Resource Management Journal, 19(1), 3-23. https://doi.org/10.1111/j.17488583.2008.00082.x
11. Brunswik, E. (1956). Perception and the representative design of psychological experiments (2nd ed.). Berkeley: University of California Press. Retrieved from https://psycnet.apa.org/record/1956-06685-000

12. Bui, H. T., Liu, G., \& Footner, S. (2016). Perceptions of HR practices on job motivation and work-life balance: Mixed drives and outcomes in a labor-intensive sector. International Journal of Manpower, 37(6), 1004-1023. https://doi.org/10.1108/IJM-122015-0214

13. Bysted, R., \& Jespersen, K. (2014). Exploring managerial mechanism that influences innovative work behavior: Comparing private and public employees. Public Management Review, 16(2), 217241. https://doi.org/10.1080/14719 037.2013 .806576

14. Cabello-Medina, C., LópezCabrales, A., \& Valle-Cabrera, R. (2011). Leveraging the innovative performance of human capital through HRM and social capital in Spanish firms. International Journal of Human Resource Management, 22(4), 807-828. https://doi.org/10.1080/09585192. 2011.555125

15. Cafferkey, K., Heffernan, M., Harney, B., Dundon, T., \& Townsend, K. (2018). Perceptions of HRM system strength and affective commitment: the role of human relations and internal process climate. The International Journal of Human Resource Management, 30(21) 3026-3048. https://doi.org/10.1080/09585192. 2018.1448295

16. Cesário, F. S. (2015). Employees perceptions of the importance of human resources management practices. Research Journal of Business Management, 9(3), 470479. http://dx.doi.org/10.3923/ rjbm.2015.470.479

17. Choi, J. H., \& Lee, K. P. (2013). Effects of employees' perceptions on the relationship between HR practices and firm performance for Korean firms. Personnel Review, 42(5), 573-594. http://dx.doi. org/10.1108/pr-12-2011-0176
18. Collins, C. J., \& Smith, K. G. (2006). Knowledge exchange and combination: The role of human resource practices in the performance of hightechnology firms. Academy of Management Journal, 49(3), 544560. http://dx.doi.org/10.5465/ AMJ.2006.21794671

19. Conway, E., \& Monks, K. (2009). Unravelling the complexities of high commitment: an employeelevel analysis. Human Resource Management Journal, 19(2), 140-158. https://doi.org/10.1111/ j.1748-8583.2009.00090.x

20. Cooke, F. L., \& Saini, D. S. (2010). (How) does the HR strategy support an innovation oriented business strategy? An investigation of institutional context and organizational practices in Indian firms. Human Resource Management, 49(3), 377-400. Retrieved from https:// www.cueb.edu.cn/docs/201511/20151123133148275333.pdf

21. Crant, J. M. (1995). The proactive personality scale and objective job performance among real estate agents. Journal of Applied Psychology, 80(4), 532-537. Retrieved from https://psycnet. apa.org/buy/1995-42526-001

22. Den Hartog, D. N., Boon, C., Verburg, R. M., \& Croon, M. A. (2013). HRM, communication, satisfaction, and perceived performance: A cross-level test. Journal of Management, 39(6), 1637-1665. https://doi. org/10.1177/0149206312440118

23. Devloo, T., Anseel, F., De Beuckelaer, A., \& Salanova, M. (2015). Keep the fire burning: Reciprocal gains of basic need satisfaction, intrinsic motivation and innovative work behavior. European Journal of Work and Organizational Psychology, 24(4), 491-504. https://doi.org/10.1080/1 359432X.2014.931326

24. Edwards, M. R. (2009). HR, perceived organizational support and organizational identification: An analysis after organizational formation. Human Resource Management Journal, 19(1), 91-115. https://doi.org/10.1111/ j.1748-8583.2008.00083.x 
25. Elorza, U., Harris, C., Aritzeta, A., \& Balluerka, N. (2016). The effect of management and employee perspectives of high-performance work systems on employees' discretionary behavior. Personnel Review, 45(1), 121-141. https://doi. org/10.1108/PR-07-2014-0167

26. Ferguson, K. L., \& Reio, T. G., Jr. (2010). Human resource management systems and firm performance. Journal of Management Development, 29(5), 471-494. https://doi. org/10.1108/02621711011039231

27. Frenkel, S. J., \& Lee, B. H. (2010). Do high performance work practices work in South Korea? Industrial Relations Journal, 41(5), 479-504. https://doi.org/10.1111/ j.1468-2338.2010.00581.x

28. Frenkel, S., Restubog, S. D., \& Bednall, T. (2012). How employee perceptions of HR policy and practice influence discretionary work effort and co-worker assistance: evidence from two organizations. International Journal of Human Resource Management, 23(20), 4193-4210. https://doi.org/10.1080/09585192. 2012.667433

29. Gardner, T. M., \& Wright, P. M. (2009). Implicit human resource management theory: a potential threat to the internal validity of human resource practice measures. The International Journal of Human Resource Management, 20(1), 57-74. https://doi. org/10.1080/09585190802528375

30. Garg, N., \& Punia, B. K. (2015). Exploring human resource audit (HRA) in Indian organizations. FIIB Business Review, 4(3), 56-63. https://doi. org/10.1177/2455265820150310

31. Giauque, D., AnderfuhrenBiget, S., \& Varone, F. (2013). HRM practices, intrinsic motivators, and organizational performance in the public sector. Public Personnel Management, 42(2), 123-150. https://doi. org/10.1177/0091026013487121

32. Greenberg, J. (2003). Creating unfairness by mandating fair procedures: The hidden hazards of a pay-for-performance plan.
Human Resource Management Review, 13(1), 41-57. https:// doi.org/10.1016/S10534822(02)00098-0

33. Guchait, P., \& Cho, S. (2010). The impact of human resource management practices on intention to leave of employees in the service industry in India: the mediating role of organizational commitment. The International Journal of Human Resource Management, 21(8), 1228-1247. https://doi.org/10.1080/09585192. 2010.483845

34. Guest, D. E. (1997). Human resource management and performance: A review and research agenda. International Journal of Human Resource Management, 8(3), 263-276. https://doi. org/10.1080/095851997341630

35. Guest, D. E. (2011). Human resource management and performance: Still searching for some answers. Human Resource Management Journal, 21(1), 3-13. https://doi.org/10.1111/j.17488583.2010.00164.x

36. Hassan, S. (2016). Impact of HRM practices on employee's performance. International Journal of Academic Research in Accounting, Finance and Management Sciences, 6(1), 15-22. https://doi.org/10.6007/IJARAFMS/v6-i1/1951

37. Hewett, R., Shantz, A., Mundy, J., \& Alfes, K. (2017). Attribution theories in Human Resource Management research: a review and research agenda. The International Journal of Human Resource Management, 29(1), 87126. https://doi.org/10.1080/09585 192.2017.1380062

38. Hinkin, T. R., \& Tracey, J. B. (2010). What makes it so great? An analysis of human resources practices among Fortune's best companies to work for. Cornell Hospitality Quarterly, 51(2), 158-170. https://doi. org/10.1177/1938965510362487

39. Höglund, M. (2012). Quid pro quo? examining talent management through the lens of psychological contracts. Personnel
Review, 41(2), 126-142. https://doi. org/10.1108/00483481211199991

40. Jiang, K., Hu, J., Liu, S., \& Lepak, D. P. (2017). Understanding employees' perceptions of human resource practices: effects of demographic dissimilarity to managers and coworkers. Human Resource Management, 56(1), 69-91. https://doi.org/10.1002/ hrm. 21771

41. Jiang, K., Lepak, D. P., Han, K., Hong, Y., Kim, A., \& Winkler, A. L. (2012). Clarifying the construct of human resource systems: Relating human resource management to employee performance. Human Resource Management Review, 22, 73-85. Retrieved from https:// www.academia.edu/1868446/ Clarifying_the_construct_of_human_resource_systems_Relating_human_resource_management_to_employee_performance

42. Judge, T. A., \& Higgins, C. A. (1999). The Big Five personality traits, general mental ability, and career success across the life span. Personnel Psychology, 52(3), 621-652. https://doi. org/10.1111/j.1744-6570.1999. tb00174.x

43. Kehoe, R. R., \& Wright, P. M. (2013). The impact of highperformance human resource practices on employee's attitudes and behaviors. Journal of Management, 39(2), 366-391. https://doi. org/10.1177/0149206310365901

44. Khan, N. R., Awang, M., \& Zulkifli, C. M. (2013). Enhancing HR outcomes through best HR practices and organizational commitment: A conceptual schema for SMEs. Indian Journal of Commerce and Management Studies, 4(1), 24-32. Retrieved from https://pdfs.semanticscholar. org/d386/d4911dbea9f51e62acc19647af3d3a6c152e.pdf

45. Khilji, S. E., \& Wang, X. (2006). Intended' and 'implemented' HRM: the missing linchpin in strategic human resource management research. International Journal of Human Resource Management, 17(7), 1171-1189. https://doi. org/10.1080/09585190600756384 
46. Kim, Y. W., \& Ko, J. (2014). HR practices and knowledge sharing behavior: Focusing on the moderating effect of trust in supervisor. Public Personnel Management, 43(4), 586-607. https://doi. org/10.1177/0091026014542342

47. Kooij, D. T., Jansen, P. G., Dikkers, J. S., \& De Lange, A. H. (2010). The influence of age on the associations between HR practices and both affective commitment and job satisfaction: A metaanalysis. Journal of Organizational Behavior, 31(8), 1111-1136. https://doi.org/10.1002/job.666

48. Korsgaard, M. A., Brodt, S. E., \& Whitener, E. M. (2002). Trust in the face of conflict: The role of managerial trustworthy behavior and organizational context. Journal of Applied Psychology, 87(2), 312-319. https://doi. org/10.1037/0021-9010.87.2.312

49. Lam, C. K., Huang, X., \& Janssen, O. (2010). Contextualizing emotional exhaustion and positive emotional display: The signalling effects of supervisors' emotional exhaustion and service climate. Journal of Applied Psychology, 95(2), 368-376. https://doi. org/10.1037/a0017869

50. Lengnick-Hall, M. L., LengnickHall, C. A., Andrade, L. S., \& Drake, B. (2009). Strategic human resource management: The evolution of the field. Human Resource Management Review, 19(2), 64-85. https://doi org/10.1016/j.hrmr.2009.01.002

51. Lepak, D. P., Liao, H., Chung, Y., \& Harden, E. H. (2006). A conceptual review of human resource management systems in strategic human resource management research. Research in Personnel and Human Resources Management, 25, 217-271. https://doi.org/10.1016/S07427301(06)25006-0

52. Li, S., Rees, C., \& Branine, M. (2019). Employees' perceptions of human resource management practices and employee outcomes. Employee Relations, 41(6), 14191433. https://doi.org/10.1108/ER01-2019-0065
53. Liao, H., Toya, D. P., Lepak, D. P., \& Hong, Y. (2009). Do they see eye to eye? Management and employee perspectives of high-performance work systems and influence processes on service quality. Journal of Applied Psychology, 94(2), 371-39. https:// doi.org/10.1037/a0013504

54. Maheshwari, S., \& Vohra, V (2015). Identifying critical HR practices impacting employee perception and commitment during organizational change. Journal of Organizational Change Management, 28(5), 872-894. https://doi.org/10.1108/JOCM-032014-0066

55. Mathis, R. L., \& Jackson, J. H. (2006). Human Resource Management $=$ Manajemen Sumber Daya Manusia. Jakarta: Salemba Empat. Retrieved from http://library.um.ac.id/freecontents/index.php/buku/detail/ human-resource-managementmanajemen-sumber-daya-manusia-robert-1-mathis-john-hjackson-38348.html

56. Messersmith, J. G., Patel, P. C., \& Lepak, D. P. (2011). Unlocking the black box: Exploring the link between high-performance work systems and performance. Journal of Applied Psychology, 96(6), 11051118. https://doi.org/10.1037/ a0024710

57. Nadda, V., Rahimi, R., Dadwal, S., \& Bhan Singh, U. (2014). Impact of HR Practices on employee's performance: Case of UK Hotel industry. Journal of Hospitality \& Tourism, 12(2), 88-111. Retrieved from https://www.researchgate. net/publication/313726347_Impact_of_HR_Practices_on_Employee's_Performance_Case_of_ UK_Hotel_Industry

58. Nawawi, H. (2001). Human resource management for competitive business. Yogyakarta: Gadjah Mada University Press.

59. Nishii, L. H., \& Wright, P. M. (2007). Variability Within Organizations: Implications for Strategic Human Resource Management (CAHRS Working Paper No. 467). Ithaca, NY: Cornell University, School of
Industrial and Labor Relations, Center for Advanced Human Resource Studies. Retrieved from https://digitalcommons.ilr.cornell. edu/cahrswp/467/

60. Nishii, L. H., Lepak, D. P., \& Schneider, B. (2008). Employee attributions of the "why" of HR practices: Their effects on employee attitudes and behaviors, and customer satisfaction. Personnel Psychology, 61(3), 503-545. https://doi.org/10.1111/ j.1744-6570.2008.00121.x

61. Ofori, D. F., Sekyere-Abankwa, V., \& Borquaye, D. (2012).

Perceptions of the human resource management function among professionals: A Ghanaian study. International Journal of Business and Management, 7(5), 159-167. Retrieved from http://ugspace. ug.edu.gh/handle/123456789/6642

62. Ostroff, C., \& Bowen, D. E. (2016). Reflections on the 2014 decade award: is there strength in the construct of HR system strength? Academy of Management Review, 41(2), 196-214. https://doi. org/10.5465/amr.2015.0323

63. Pombo, G., \& Gomes, J. (2018). How does work engagement mediate the association between human resources management and organizational performance? Problems and Perspectives in Management, 16(3), 63-79. http://dx.doi.org/10.21511/ ppm.16(3).2018.06

64. Ramsay, H., Scholarios, D., \& Harley, B. (2000). Employees and high-performance work systems: Testing inside the black box. British Journal of Industrial Relations, 38(4), 501-531. https:// doi.org/10.1111/1467-8543.00178

65. Sanders, K., Dorenbosch, L., \& de Reuver, R. (2008). The impact of individual and shared employee perceptions of HRM on affective commitment: Considering climate change. Personnel Review, 37(4), 412-425. https://doi. org/10.1108/00483480810877589

66. Scheible, A. C., \& Bastos, A. V. (2013). An examination of human resource management practices' influence on Organizational Commitment and 
Entrenchment. BAR-Brazilian Administration Review, 10(1), 5776. https://doi.org/10.1590/S180776922012005000011

67. Shaukat, H., Ashraf, N., \& Ghafoor, S. (2015). Impact of human resource management practices on employees performance. Middle-East Journal of Scientific Research, 23(2), 329-338. Retrieved from https://pdfs.semanticscholar.org/6acb/e7db4c572ce76d8238237c0f784ce5ff3cda.pdf

68. Snape, E., \& Redman, T. (2010). HRM Practices, organizational citizenship behavior, and performance: a multi-level analysis. Journal of Management Studies, 47(7), 1219-1247. https://doi.org/10.1111/j.14676486.2009.00911.x

69. Stumpf, S. A., Doh, J. P., \& Tymon, J. G. (2010). The strength of HR practices in India and their effects on employee career success, performance, and potential. Human Resource Management, 49(3), 353-375. https://doi. org/10.1002/hrm.20361

70. Subyantoro, A. (2009). Individual Characteristics, Job Characteristics, Organizational Characteristics and Job Satisfaction. Jurnal Manajemen Dan Kewirausahaan, 11(1), 11-19. Retrieved from http://jurnalmanajemen.petra.ac.id/index.php/man/ article/view/17740/17661

71. Suttapong, K., Srimai, S., \& Pitchayadol, P. (2014). Best practices for building high performance in human resource management. Global Business and Organizational Excellence, 33(2), 39-50. https://doi.org/10.1002/ joe. 21532

72. Thite, M., Wilkinson, A., \& Shah, D. (2012). Internationalization and HRM strategies across subsidiaries in multinational corporations from emerging economies: A conceptual framework. Journal of World Business, 47(2), 251258. https://doi.org/10.1016/j. jwb.2011.04.012

73. Tian, A. W., Cordery, J., \& Gamble, J. (2016). Staying and performing: How human resource management practices increase job embeddedness and performance.
Personnel Review, 45(5), 947-968. https://doi.org/10.1108/PR-092014-0194

74. Tracey, J. B. (2012). A contextual, flexibility-based model of the HR-firm performance relationship. Management Decision, 50(5), 909-924. https://doi. org/10.1108/00251741211227609

75. Tsui, A. S., Pearce, J. L., Porter, L. W., \& Tripoli, A. M. (1997). Alternative Approaches to the Employee-Organization Relationship: Does Investment in Employees Pay Off? Academy of Management Journal, 40(5), 1089-1121. https://doi. org/10.2307/256928

76. Úbeda-García, M., ClaverCortés, E., Marco-Lajara, B., Zaragoza-Sáez, P., \& Gascía-Lillo, F. (2018). High performance work system and performance: Opening the black box through the organizational ambidexterity and human resource flexibility. Journal of Business Research, 88, 397-406. https://doi.org/10.1016/j. jbusres.2017.12.045

77. Veloso, A. L. (2010). The workers perceptions about human resource management function. In S. T. Menoned (Ed.), Competing Values in an Uncertain Environment: Managing the Paradox (pp. 6470). Retrieved from http:// repositorium.sdum.uminho.pt/ bitstream/1822/12178/1/Ana\%20 Veloso\%20HRM\%20perceptions\%202010.pdf

78. Vermeeren, B., Steijn, B., Tummers, L., Lankhaar, M., Poerstamper, R. J., \& Van Beek, S. (2014). HRM and its effect on employee, organizational and financial outcomes in health care organizations. Human Resources for Health, 12(1), 35-56. https://doi. org/10.1186/1478-4491-12-35

79. Wang, M. K., \& Hwang, K. P. (2012). The impact of employee perceptions of human resource management systems on job satisfaction and organizational commitment during privatization the transformations of privatization: An empirical study of telecommunication corporation in Taiwan. Asia Pacific Management Review, 17(3),
321-342. https://doi.org/10.6126/ APMR.2012.17.3.06

80. Wheeler, A. R., Harris, K. J., \& Harvey, P. (2010). Moderating and mediating the HRM effectiveness Intent to turnover relationship: The roles of supervisors and job embeddedness. Journal of Managerial Issues, 22(2), 182-196. Retrieved from https://www.jstor. org/stable/20798904

81. Wright, P. M., \& Nishii, L. H. (2007). Strategic HRM and organizational behavior: Integrating multiple levels of analysis (CAHRS Working Paper No. 468). Retrieved from https://digitalcommons.ilr. cornell.edu/cahrswp/468

82. Wright, P., \& Boswell, W. (2002). Desegregating HRM: A review and synthesis of micro and macro human resource management research. Journal of Management, 28(3), 247-276. https://doi. org/10.1177/014920630202800302

83. Wyer Jr, R. S. (2012). A theory of social information processing. In P. A. M. Van Lange, A. W. Kruglanski, \& E. T. Higgins (Eds.), Handbook of theories of social psychology (pp. 156-177). Sage Publications Ltd. https://doi. org/10.4135/9781446249215.n9

84. Yadav, S. K., \& Yadav, D. (2013). Exploring HPWPs in Indian organizations. Maharaja Agarshen Journal of Management, 12(2), 112-110.

85. Yamamoto, H. (2013). The relationship between employees perceptions of human resource management and their retention: From the viewpoint of attitudes toward job-specialties. International Journal of Human Resource Management, 24(4), 747767. https://doi.org/10.1080/09585 192.2012 .697478

86. Young-Thelin, L., \& Boluk, K. (2012). A case study of human resource practices in small hotels in Sweden. Journal of Human Resources in Hospitality and Tourism, 11(4), 327-353. https:// doi.org/10.1080/15332845.2012.6 90683 